\title{
DETEKSI EKSPRESI WAJAH MENGGUNAKAN TENSORFLOW
}

\author{
Mohamad Ihsan ${ }^{1}$, Ratih Kumalasari Niswatin ${ }^{2}$, Daniel Swanjaya ${ }^{3}$ \\ Teknik Informatika, Fakultas Teknik, Universitas Nusantara PGRI Kediri \\ Jln. Kh. Ahmad Dahlan Gg. II No.6 Mojoroto, Kota Kediri \\ E-mail: ${ }^{1}$ Lfihsan18@gmail.com, ${ }^{2}$ ratih.workmail@gmail.com, ${ }^{3}$ daniel@unpkediri.ac.id
}

\begin{abstract}
ABSTRAKS
Ekspresi wajah adalah merupakan perubahan bentuk raut muka wajah dalam menanggapi keadaan perasaan, niat dan komunikasi sosial seseorang. Ekspresi wajah ini sangat bagus untukk di teliti karena merupakan alat komunikasi non verball yang biasa digunakan oleh manusia 'untuk menggambarkan keadaan emosi atau perasaan dan untuk menyampaikan pesan sosial di kehidupan sehari-hari. Penelitian ini menggunakan machine learning open source library Tensorflow dengan mengguanakan metode Convolutional Neural Network (CNN) yang dirancang khusus untuk pengenalan dan menentukan klasifikasi terhadap 7 ekspresi dasar wajah manusia ditambah ekspresi netral, metode ini memiliki hasil paling signifikan dalam hal pengenalan citra. Pemerataan distribusi data akan dilakukan untuk meningkatkan kinerja model. Hasil dari pengujian analisis di dapatkan hasil parameter optimal batch 32, epoch 100 dan dropout 0.6 dengan tingkat akurasi training 62.24\%, akurasi validasi $62,44 \%$, training loss 4,54\% dan validation loss 4,02\%. Di akhir penelitian ini, penulis melakukan percobaan pendeteksian ekspresi wajah dengan video secara realtime.
\end{abstract}

Kata Kunci: Ekspresi Wajah, Tensorflow, $C N N$

\begin{abstract}
Facial expression is the change in facial shape in an emergency of one's emotions, intentions, or social communication. This facial expression is very good to examine because it is a non-verball communication tool commonly used by humans to describe emotional states or feelings and to convey social messages in everyday life. This research uses machine learning open source library Tensorflow using the Convolutional Neural Network (CNN) method which is specially designed for recognition and classification of 7 basic human facial expressions plus neutral expressions, this method has the most significant results in terms of image recognition. Even distribution of data is done to improve model performance. The results of the analysis test obtained the optimal results for batch 32, epoch 100 and dropout 0.6 with 62.24\% training accuracy, 62.44\% validation value, $4.54 \%$ training loss and $4.02 \%$ validation loss. At the end of this study, the authors conducted an experiment in realtime detection of facial expressions with video.
\end{abstract}

Keywords : Facial Expression, Tensorflow and CNN

\section{PENDAHULUAN}

\subsection{Latar Belakang}

Ekspresi wajah adalah merupakan perubahan bentuk raut muka wajah dalam menanggapi keadaan perasaan, niat dan komunikasi sosial seseorang (Tian, Y.,Kanade,dkk,2011). Perwujudan pada wajah manusia secara tidak lansung memberi ungkapan akan suatu bentuk perasaan, keinginan, serta tujuan tertentu. Setiap mimik wajah memiliki pemaknaan yang dapat terbaca oleh orang lain, maka melalui mimik wajah dapat diketahui apa yang sedang terjadi dan bagaimana perasaan seseorang (Putra, Tezar Maas, 2016).

Dalam deteksi ekspresi wajah, terdapat sejumlah tantangan yaitu posisi bentuk wajah, skala, ekspresi, wajah yang terhalang objek lain, dan kondisi pencahayaan yang kurang (Yang,S.,Luo,dkk,2016). Pendeteksi ekspresi wajah ini bertujuan untuk mencari bentuk, posisi dan juga skala wajah di sebuah citra dan mengembalikannya ke kordinat area wajah untuk setiap wajah yang telah terdeteksi. Sedangkan face alignment ini bertujuan untuk menyerasikan wajah yang terdeteksi dengan cara menggunakan satu set titik referensi yang terletak di dalam citra (Trigueros,D.S.,Meng,dkk,2018). Seiring dengan berkembangnya, metode-metode pengenalan ekspresi wajah atau face detection dan jua meningkatnya kinerja perangkat keras, banyak penelitian yang tidak hanya melakukan pendeteksian wajah tetapi juga melakukan pengenalan wajah, termasuk di dalamnya pengenalan ekspresi wajah. Pada umumnya, aplikasi pengenalan ekspresi wajah biasanya terdiri dari 4 bagian, yaitu face detection, face alignment, feature extraction dan feature maching (Li, S. Z., \& Jain, A. K., 2011).

Ekspresi wajah ini sangat bagus untukk di teliti karena merupakan alat komunikasi non verball yang biasa digunakan oleh manusia 'untuk menggambarkan keadaan emosi atau perasaan dan untuk menyampaikan pesan sosial di kehidupan sehari-hari. Seseorang terkadang ingin menutupnutupi perasaan atau emosinya, tetapi hal ini sangat sulit dilakukan karena ekspresi wajah mereka biasanya akan menunjukan perasaan yang sedang 
dialami. Misalnya, seseorang ingin menutupi perasaan bencinya terhadap orang lain, tetapi pada saat tertentu tanpa sengaja ia akan menunjukkan perasaannya tersebut melalui ekspresi wajah yang ditampilkan. Sebaliknya, banyak orang yang salah dalam membaca ekspresi sesorang karena hanya melihat sekilas saja. Hal ini tentunya memerlukan pengamatan terus menerus terhadap perubahan ekspresi wajah seseorang. Namun hal ini tidak bisa dilakukan oleh seseorang secara langsung karena pada saat tertentu, mereka akan mengalami kejenuhan yang menghasilan ketidaktelitian.

\subsection{Referensi \\ 1.2.1 Definisi Citra}

Citra merupakan salah satu bagian komponen dari multimedia yang memiliki peranan penting karena berisi informasi dalam bentuk visual. Citra ini memiliki banyak informasi yang disampaikan dibandingkan dengan informasi dalam bentuk tulisan. tetapi tidak semua citra digital memiliki kualitas yang baik,sehingga citra tersebut tidak bisa menampilkan informasi yang akurat, Hal ini umumnya terjadi pada citra yang mempunyai nilai resolusi rendah (Mustaqim Nailul, 2011).

\subsubsection{Definisi Tensorflow}

Tensorflow adalah library perangkat lunak yang dikembangkan oleh Tim Google, yang bertujuan untuk mengerjakan pembelajaran mesin dan jaringan syaraf dalam penelitiannya. Tensorflow menggabungkan aljabar komputasi dengan teknik optimasi kompilasi, yang memfasilitasi perhitungan banyak ekspresi matematika (Taufiq, Imam, 2018). Fitur utama yang terdapat dalam tensorflow adalah:

1. Pemrograman pendukung jaringan syaraf dalam dan teknik machine learning.

2. Mendefinisikan, mengoptimalkan, dan menghitung secara matematis ekspresi wajah yang melibatkan array multidimension (tensors).

3. Pemakaian GPU (Graphics Processing Unit) yang efisien, mengotomasi manajemen dan mengoptimalisasikan memori yang sama terhadap data yang dipakai. Tensorflow mampu menulis kode yang sama dan menjalankannya di CPU atau GPU. Lebih khususnya lagi tensorflow dapat mengetahui bagian mana yang harus dipindahkan ke GPU.

Skalabilitas komputasi yang tinggi pada keseluruhan mesin terhadap kumpulan data yang besar.

\section{PEMBAHASAN}

Klasifikasi ekspresi wajah dalam penelitian ini menggunakan metode CNN yang dijabarkan menjadi dua bagian, yaitu proses training dan proses deteksi. Dimana proses training ini merupakan pembuatan model yang akan dipakai sebagai acuan klasifikasi, sedangkan pada proses deteksi merupakan penerapan model terhadap data uji atau data asing yang belum pernah digunakan. Pada proses perancangan digunakan bahasa pemrograman php dengan menggunakan library Tensorflow.

Pengembangan metode CNN di dalam penelitian ini menggunakan data dari The Facial Expression Recognition 2013 (FER-2013) yang dipopulerkan pada International Conference on Machine Learning (ICML) 2013. FER-2013 sendiri berisi 35.887 citra grayscale bentuk wajah yang berukuran $48 \times 48$, terdiri dari 7 jenis ekspresi yang berbeda. Data tersebut telah dilabeli dan di klasifikasikan menjadi 7 kelas dengan indek 0 sampai 6 seperti pada Tabel 1.

Tabel 1. Kelas ekspresi pada FER2013

\begin{tabular}{lll}
\hline Label & Jenis Ekspresi & Jumlah \\
\hline $\mathbf{0}$ & Marah (Angry) & 4593 \\
$\mathbf{1}$ & Jijik (Disgust) & 547 \\
$\mathbf{2}$ & Takut (Fear) & 5121 \\
$\mathbf{3}$ & Bahagia (Happy) & 8989 \\
$\mathbf{4}$ & Sedih (Sad) & 6077 \\
$\mathbf{5}$ & Terkejut (Surprise) & 4002 \\
$\mathbf{6}$ & Netral (Neutral) & 6198 \\
\hline
\end{tabular}

Pada Tabel 2 merupakan arsitektur CNN yang digunakan untuk melakukan proses training dengan standar fully convolutional neural network yang terdiri dari 10 lapisan konvolusi, ReLu, Batch Normalization, Dropout dan Global Max Pooling. Arsitektur ini mempunyai kurang lebih 600.000 parameter training. Nilai insialisasi dropout diberikan dengan nilai 0.5 sebagai titik tengah antara 0 dan 1 (Wu Haibing, Xiaodong Gu, 2015).

\section{Tabel 2. Arsitektur CNN}

\begin{tabular}{|l|l|}
\hline \multicolumn{1}{|c|}{ Proses } & \multicolumn{1}{|c|}{ Parameter } \\
\hline $\begin{array}{l}\text { Konvolusi Batch } \\
\text { Normalization }\end{array}$ & Filters $=16$, kernel $=(7,7)$, \\
Padding $=1$
\end{tabular}


Arsitektur diaplikasikan pada proses training beserta alur proses pada Gambar 1. Pada alur proses ini, dibagi menjadi tiga bagaian proses yaitu, preproses data, proses $\mathrm{CNN}$ dan proses pembuatan model. Pada bagian peproses, akan di lakukan normaliasi data agar nilai data yang diproses berada diantara -1 dan 1 dengan memakai persamaan (1), sehingga dapat lebih cepat diproses oleh neural network. Dimana nilai $\mathrm{x}$ adlah nilai normalisasi dan nila $\mathrm{p}$ adalah nilai awal dari data.

$x=((p \div 255)-0,5) \times 2$
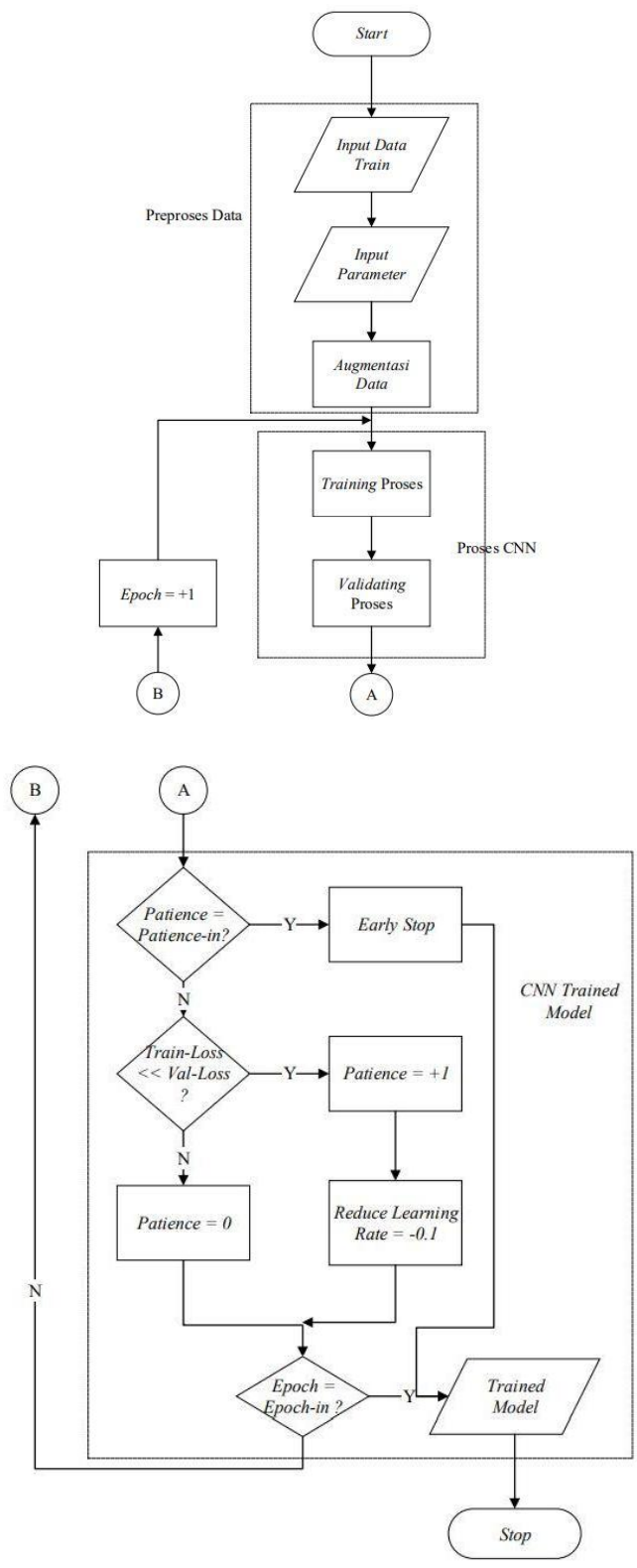

Gambar 1. Flowchart proses training

Selain proses training, juga akan dilakukan proses augmentasi data beserta cara alterasi berupa pergeseran citra sumbu x, pergeseran citra sumbu $y$, rotasi citra, memperkecil dan memperbesar citra, serta membalikan citra secara horizontal. Dalam penentuan nilai parameter awal seperti batch, epoch dan dropout, akan ditentukan pada tahap preproses data, untuk selanjutnya akan dirubah dengan maksud menemukan parameter optimal. Pada tahap proses $\mathrm{CNN}$, data akan dibagi menjadi dua bagian yaitu 28.704 data proses training dan 7.184 data proses validasi. Proses ini akan menghasilkan nilai akurasi dan nilai loss. Selanjutnya untuk proses validasi dan training akan dianalisa guna mencari model paling optimal dengan nilai akurasi validasi paling tinggi dan nilai loss paling rendah[13]. Pembentukan pada model proses CNN trained model ini melewati beberapa tahap untuk mencegah model akhir, demi mencapai overfit atau stagnansi yang optimal. Variabel patience ini akan digunakan untuk mencegah overfit, dimana nilai ini merupakan nilai maksimum epoch yang akan digunakan jika tidak ada perubahan nilai pada nilai loss validasi (Albawi Saad, Mohammed Tareq Abed, dkk, 2017).

Variabel ini akan terhubung menggunakan fungsi early stop, jika nilai patience mencapai maksimum data maka fungsi early stop akan memaksa menjalankan proses training untuk berhenti. Selain itu jika nilai patience mencapai seperempat nilai maksimum, maka fungsi lainnya bernama reduce learning rate akan dijalankan untuk mengurangi nilai learning rate sebesar 0,1 dari adam optimizer. Proses training akan dilakukan berulang kali dengan melakukan perubahan pada parameter berdasarkan Tabel 3. Proses ini dilakukan dengan Langkahlangkag seperti pada Gambar 2 untuk menentukan nilai parameter optimal dari model yang akan dihasilkan. Proses training dilakukan pada komputer dengan spesifikasi CPU AMD Ryzen ${ }^{\mathrm{TM}} 5-3550 \mathrm{H}$ dengan GTX1050_V3G, RAM 8 GB dan ROM 1 TB.

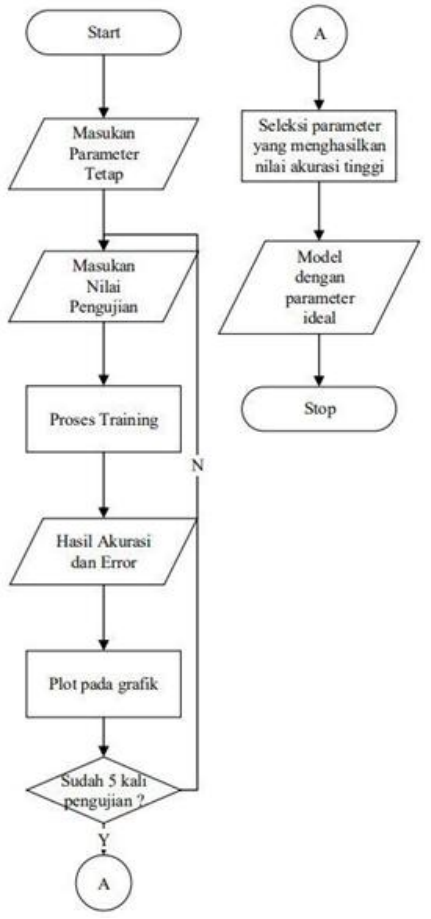

Gambar 2. Flowchart akurasi 


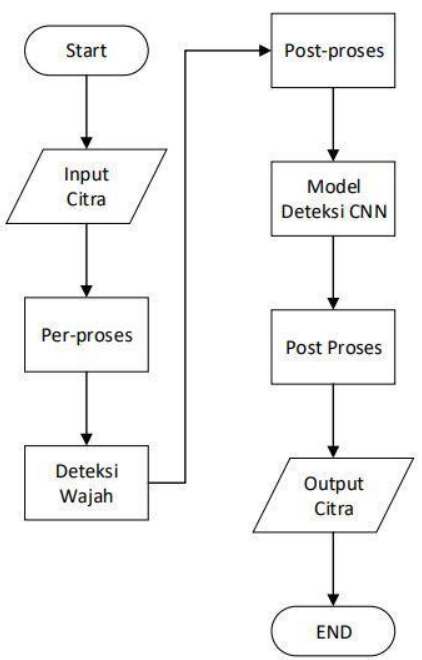

Gambar 3. Flowchart proses deteksi

Tabel 3. Parameter Uji

\begin{tabular}{|l|l|l|l|l|l|l|l|l|}
\hline \multirow{2}{*}{$\begin{array}{c}\text { Parameter } \\
\text { uji }\end{array}$} & \multicolumn{3}{|l|}{ Parameter Tetap } & \multicolumn{5}{|c|}{ Nilai Percobaan } \\
\cline { 2 - 10 } & $\begin{array}{l}\text { Batch } \\
\text { Time }\end{array}$ & Epoch & $\begin{array}{l}\text { Prop } \\
\text { out }\end{array}$ & 1 & 2 & 3 & 4 & 5 \\
\hline Batch Time & - & 50 & 0 & 16 & 32 & 64 & 128 & 256 \\
\hline Epoch & $\begin{array}{l}\text { Best } \\
\text { Batch } \\
\text { Time }\end{array}$ & - & 0 & 30 & 50 & 70 & 90 & 100 \\
\hline Drop Out & $\begin{array}{l}\text { Best } \\
\text { Batch } \\
\text { Time }\end{array}$ & $\begin{array}{l}\text { Best } \\
\text { Epoch }\end{array}$ & - & 0,2 & 0,4 & 0,5 & 0,6 & 0,8 \\
\hline
\end{tabular}

Proses deteksi ini menggunakan model feed forward dengan data yang akan dimasukan pada model yang sudah optimal, seperti pada Gambar 3 . Proses ini nantinya akan terbagi menjadi dua bagian yaitu proses deteksi wajah dan proses deteksi emosi. Pada proses deteksi ekspresi wajah, menggunakan metode haar cascade classifier guna untuk menghasilkan posisi raut muka wajah pada data yang akan diidentifikasi jenis ekspresinya (Zufar Muhamad \& Setiyono Budi, 2016).

Selanjutnya hasil dari deteksi wajah ini akan diidentifikasi dengan output berupa label ekspresi yang sudah ditentukan oleh system. Pada proses analisa nilai akurasi, presisi dan recall, akan dilakukan menggunakan metode literasi data dengan data citra asing sebanyak 3.589 yang belum dipakai pada proses training dan terbagi menjadi 7 variasi ekspresi seperti ditunjukan pada Tabel 4. Hasil deteksi ekspresi pada setiap literasinya akan masukan pada tabel confussion matix yang selanjutnya akan dihitung nilai akurasi, presisi, dan recall menggunakan persamaan (2)(3) dan (4). Proses akuisisi data dilakukab seperti pada flowchart Gambar 4

$$
\begin{aligned}
& \text { Akurasi }=\frac{T P+T N}{T P+T N+F P+\mathrm{FN}} \\
& \text { Presisi }=\frac{T P}{T P+F P}
\end{aligned}
$$

Recall $=\frac{T P}{T P+F \mathrm{~N}}$

Tabel 4. Jenis ekspresi

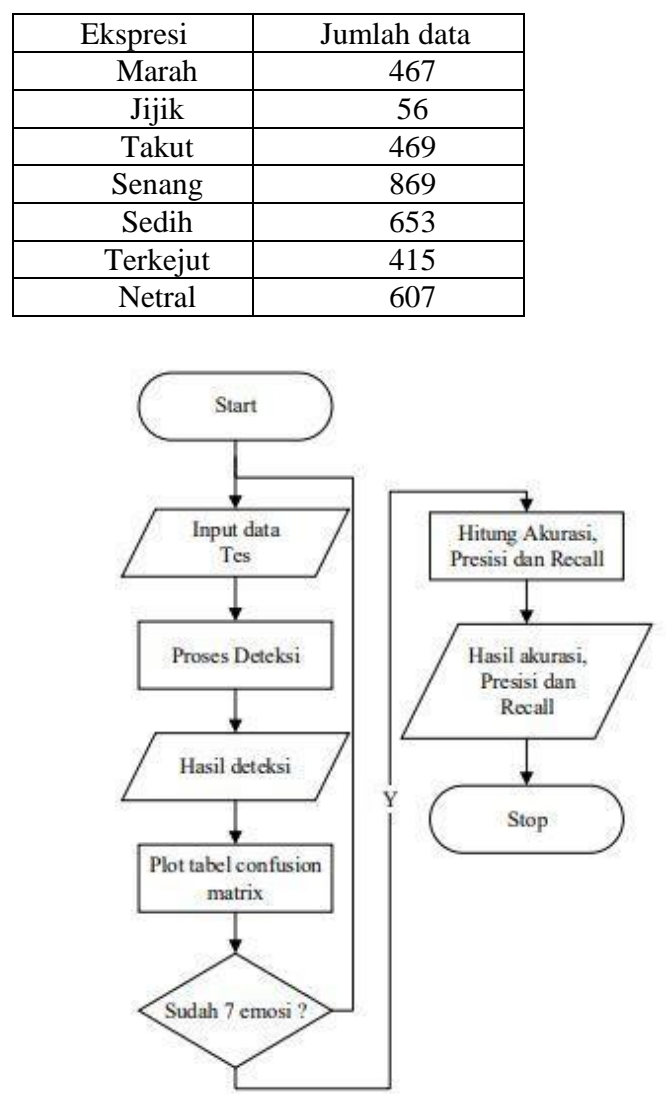

Gambar 4. Flowchart Akurasi Deteksi

\section{HASIL DAN PEBAHASAN}

Normalisasi data pada tahap preproses dengan menggunakan Persamaan (1) ditunjukan pada Tabel 5. Nilai piksel data yang sebelumnya besar dinormalisasi agar berada pada jarak -1 sampai 1 .

\begin{tabular}{|c|c|c|}
\hline Nilai $P$ & Persamaan & Nilai $X$ \\
\hline 70 & \multirow{11}{*}{$\mathrm{x}=((\mathrm{p} / 255)-(0,5)) * 2$} & 0,45 \\
\hline 80 & & $-0,37$ \\
\hline 82 & & $-0,35$ \\
\hline 72 & & $-0,4$ \\
\hline 58 & & $-0,54$ \\
\hline 60 & & $-0,5$ \\
\hline 63 & & $-0,5$ \\
\hline 54 & & $-0,57$ \\
\hline 151 & & 0,18 \\
\hline 147 & & 0,15 \\
\hline 155 & & 0,21 \\
\hline
\end{tabular}

Tabel 5. Normalisasi nilai awal

Augmentasi data memasukan nilai parameter untuk masing-masing augmentasi ditunjukan pada Tabel 6 dan hasil dari augmentasi ditunjukan pada Gambar 6. Untuk nilai rotasi dimasukan nilai 90, dimana sistem akan melakukan rotasi citra secara 
acak pada data dengan rotasi antara - $90^{\circ}$ sampai $90^{\circ}$. Nilai pergesaran pada sumbu $\mathrm{x}$ diberikan dengan nilai $-10,10$ dimana citra akan bergeser dengan nilai 10 piksel ke kiri dan 10 piksel ke kanan, begitu pula dengan pergeseran sumbu y dengan parameter yang sama dimana citra akan bergeser keatas dan kebawah. Nilai pembesaran citra diberikan dengan nilai 0,7 dan 1,3 dimana data akan diubah perbesarannya dengan jarak antara $70 \%$ sampai $130 \%$. Terakhir citra akana dibalikan secara horizontal, sehingga dengan menggunakan proses augmentasi didapat 5 variasi data citra input yang dihasilkan dari 1 citra input.

Tabel 6. Parameter augmentasi

\begin{tabular}{|l|l|}
\hline Parameter & Nilai \\
\hline Rotation_range & 90 \\
\hline Width_shift_rang & -10.10 \\
\hline Height_shift_range & -10.10 \\
\hline Zoom_range & $0.7,1,3$ \\
\hline Horizontal_flip & TRUE \\
\hline
\end{tabular}

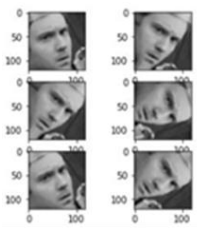

(a)
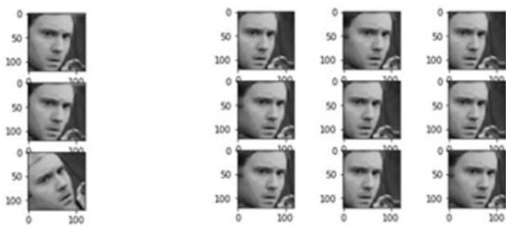

(b)
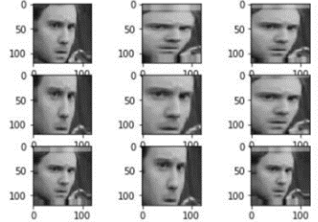

(d)

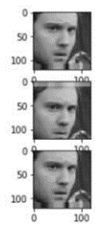

(c)
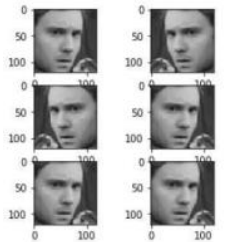

(e)
Gambar 6. Hasil Augmentasi data (a) Augmentasi Rotasi; (b) Pergeseran Sumbu x; (c) Pergeseran Sumbu y; (d) Perbersaran; (e) Pembalikan Horisontal

Setelah data disiapkan kemudian dilakukan proses training terhadap data dengan menggunakan variasi parameter uji pada Tabel 2. Hasil pelatihan terhadap beberapa parameter uji tersebut, didapatkan hasil akurasi dan loss yang dianggap paling baik untuk masing-masing skenario ditunjukan pada Tabel 7 sampai dengan Tabel 9. Dari data tersebut dapat diambil parameter paling optimal dari tiga parameter batch, epoch dan dropout yang menghasilkan nilai paling baik dari semua skenario yakni dengan nilai parameter batch 32, epoch 100 , dan dropout 0,6. Parameter tersebut menghasilkan nilai akurasi training $62.24 \%$, akurasi validasi $62.44 \%$, nilai training loss $4.54 \%$ dan validation loss $4.02 \%$.

Tabel 7. Akumulasi Skenario I

\begin{tabular}{|c|c|c|c|c|}
\hline Batch & Acc & Val_acc & Loss & Val_loss \\
\hline 16 & $54,91 \%$ & $60,35 \%$ & $4,96 \%$ & $4,38 \%$ \\
\hline 32 & $55,15 \%$ & $60,59 \%$ & $4,93 \%$ & $4,36 \%$ \\
\hline 64 & $55,11 \%$ & $59,92 \%$ & $4,91 \%$ & $4,40 \%$ \\
\hline 128 & $52,14 \%$ & $57,91 \%$ & $5,21 \%$ & $4,62 \%$ \\
\hline 256 & $55,03 \%$ & $59,36 \%$ & $4,97 \%$ & $4,49 \%$ \\
\hline
\end{tabular}

Tabel 8. Akumulasi skenario ii

\begin{tabular}{|c|c|c|c|c|}
\hline Epoch & acc & val_acc & loss & val_loss \\
\hline 70 & $56,20 \%$ & $60,42 \%$ & $4,82 \%$ & $4,30 \%$ \\
\hline 90 & $56,61 \%$ & $62,15 \%$ & $4,77 \%$ & $4,20 \%$ \\
\hline 100 & $57,60 \%$ & $62,80 \%$ & $4,65 \%$ & $4,11 \%$ \\
\hline 120 & $54,71 \%$ & $60,41 \%$ & $4,93 \%$ & $4,31 \%$ \\
\hline 150 & $55,52 \%$ & $60,46 \%$ & $4,90 \%$ & $4,31 \%$ \\
\hline
\end{tabular}

Tabel 9. Akumulasi skenario iii

\begin{tabular}{|c|c|c|c|c|}
\hline Epoch & acc & val_acc & loss & val_loss \\
\hline 0.2 & $58,06 \%$ & $62,78 \%$ & $4,64 \%$ & $4,14 \%$ \\
\hline 0.4 & $60,63 \%$ & $64,22 \%$ & $4,32 \%$ & $4.00 \%$ \\
\hline 0.6 & $62.24 \%$ & $62,44 \%$ & $4,54 \%$ & $4,02 \%$ \\
\hline 0.8 & $45,65 \%$ & $52,01 \%$ & $5,91 \%$ & $5,15 \%$ \\
\hline 1 & $75,31 \%$ & $66,72 \%$ & $2,76 \%$ & $4,12 \%$ \\
\hline
\end{tabular}

Hasil parameter optimal diujikan kembali pada data asing dengan hasil ditunjukan pada Tabel 10 . Nilai persentasi cell yang ditandai merupakan nilai true positive atau persentasi keberhasilan sistem dalam menebak emosi yang benar. Nilai persentasi pada baris dari tabel merupakan nilai false positive yakni nilai dimana sistem menebak emosi yang salah dengan benar, sedangkan pada nilai kolom merupakan nilai false negative yakni nilai dimana sistem menebak emosi yang salah dengan salah. Dari nilai-nilai persentasi tersebut dapat dihitung menggunakan persamaan (2), (3), dan (4) sehingga menghasilkan nilai akurasi $77 \%$, presisi $72 \%$ dan recall $74 \%$. Gambar 7 menunjukan hasil dari deteksi pada 7 ekpresi wajah yang ditentukan dengan menggunakan citra input secara realtime.

\section{Tabel 10. Confussion matrix}

\begin{tabular}{|c|c|c|c|c|c|c|c|}
\hline & Marah & Jijik & Takut & Senang & Sedih & Terkejut & Netral \\
\hline Marah & $70 \%$ & $1 \%$ & $10 \%$ & $4 \%$ & $2 \%$ & $3 \%$ & $10 \%$ \\
\hline Jijik & $26 \%$ & $\begin{array}{c}55 \\
\%\end{array}$ & $5 \%$ & $4 \%$ & $5 \%$ & $2 \%$ & $3 \%$ \\
\hline Takut & $12 \%$ & $1 \%$ & $45 \%$ & $5 \%$ & $20 \%$ & $7 \%$ & $11 \%$ \\
\hline Senang & $2 \%$ & $0 \%$ & $2 \%$ & $87 \%$ & $2 \%$ & $2 \%$ & $5 \%$ \\
\hline Sedih & $9 \%$ & $1 \%$ & $10 \%$ & $6 \%$ & $55 \%$ & $1 \%$ & $19 \%$ \\
\hline Terkejut & $3 \%$ & $0 \%$ & $10 \%$ & $5 \%$ & $2 \%$ & $80 \%$ & $0 \%$ \\
\hline Netral & $5 \%$ & $0 \%$ & $5 \%$ & $9 \%$ & $3 \%$ & $2 \%$ & $75 \%$ \\
\hline
\end{tabular}




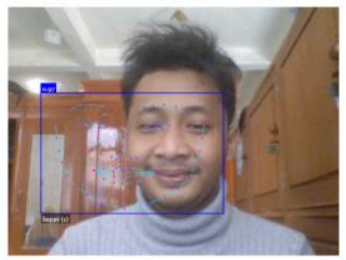

(a)

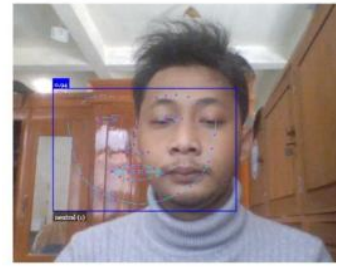

(c)

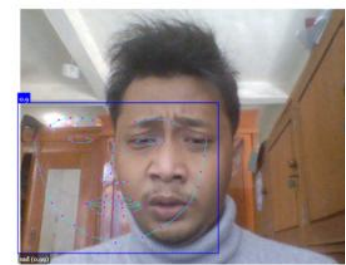

(e)

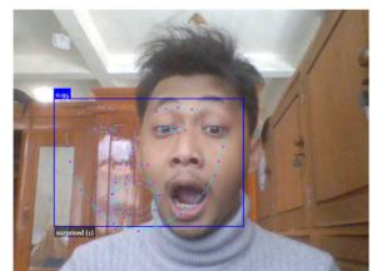

(b)

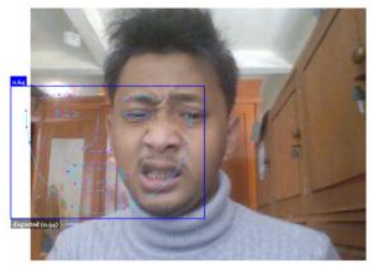

(d)

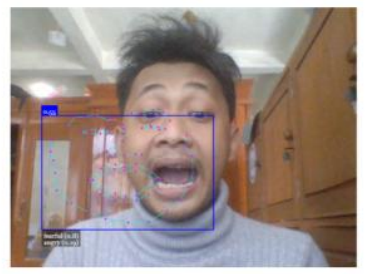

(f)

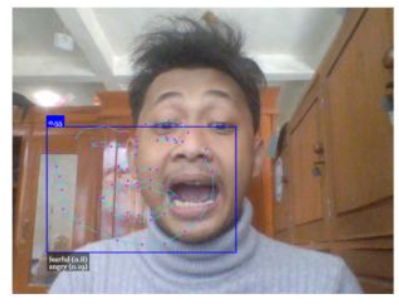

(g)

Gambar 7. Hasil Deteksi 7 ekspresi : (a) Senang; (b) Terkejur; (c) Netral; (d) Jijik; (e) Sedih (f) Marah; (g) takut

\section{KESIMPULAN}

Berdasarkan hasil dari penelitian, klasifikasi ekspresi wajah menggunakan metode Convolutional Neural Network (CNN) dengan menggunakan library TensorFlow berhasil diimplementasikan untuk mendeteksi ketujuh ekspresi yakni marah, senang, sedih, jijik, terkejut takut dan neutral. Dihasilkan nilai parameter optimal batch 32, epoch 100, dan dropout 0,6; dengan akurasi training $61,15 \%$; akurasi validasi $64,54 \%$; training loss 4,29\%; dan validasi loss 3,96\%; dari hasil akurasi tersebut dapat disimpulkan bahawa sistem tidak mengalami overfit karena nilai akurasi validasi lebih besar dari nilai akurasi training. Parameter Optimal tersebut diujikan kepada data asing yang belum pernah di deteksi sebelumnya dan menghasilkan nilai akurasi deteksi $67 \%$, presisi $67 \%$ dan recall $66 \%$.

\section{PUSTAKA}

Tian, Y., Kanade, T., \& Cohn, J. F. 2011. Facial Expression Recognition. In Handbook of Face Recognition (pp. 487-519). https://doi.org/ 10.1007/978-0-85729-932-1.

Putra, Tezar Maas. 2016. Ekspresi Wajah Dalam Karya Lukis Surrealis. Jurnal Fakultas Bahasa dan Seni Universitas Negeri Padang.

Yang, S., Luo, P., Loy, C. C., \& Tang, X. (2016). WIDER FACE: A face detection benchmark. Proceedings of the IEEE Computer Society Conference on Computer Vision and Pattern Recognition, 2016-Decem, 5525-5533. https://doi.org/10.1109/CVPR.2016.596.

Trigueros, D. S., Meng, L., \& Hartnett, M. (2018). Face Recognition: From Traditional to Deep Learning Methods. ArXiv, (October 2018).

Li, S. Z., \& Jain, A. K. (2011). Handbook of Face Recognition. (S. Z. Li1 \& A. K. Jain, Eds.), Handbook of Face Recognition (2nd ed.). Springer. https://doi.org/10.2990/29_1_103.

Mustaqim Nailul (2011), Peningkaatan Kualitas Citra Digital Menggunakan Metode Super Resolusi, Universitas Syiah Banda Aceh, Banda Aceh.

Taufiq, Imam (2018). "Deep Learning Untuk Deteksi Tanda Nomor Kendaraan Bermotor Menggunakan Algoritma Convolutional Neural Network Dengan Python Dan Tensorflow". Skripsi. Program Studi Sistem Informasi Sekolah Tinggi Manajemen Informatika dan Komputer AKAKOM.

Wu Haibing, Xiaodong Gu, "Max-Pooling Dropout for Regularization of Convolutional Neural Networks", di ICONIP, 2015, Lecture Notes in Computer Science vol. 9489.

Goodfellow Ian, Bengio Yoshua and Courville Aaron, Deep Learning, 2016.

Albawi Saad, Mohammed Tareq Abed dan Alzawi Saad, "Understanding of a Convolutional Neural Network", ICET, 2017.

Zufar Muhamad dan Setiyono Budi, "Convolutional Neural Networks untuk Pengenalan Wajah Secara Real-Time", Institut Teknologi Sepuluh Nopember, Jurnal Sains dan Seni ITS Vol. 5, No.2, 2016. 